

\title{
Das doppelgänger Freud A review of Freud's Patients: A Book of Lives
}

\section{Robert M Kaplan}

Clinical Associate Professor, Graduate School of Medicine, University of Wollongong, Wollongong, Australia

\begin{abstract}
Sigmund Freud described very few cases, but more details have come out over the years despite the efforts of the Freud estate to embargo embarrassing records.

Mikkel Borch-Jacobsen, a leading historian of psychoanalysis, has described thirty-eight patients treated by Freud. He refrains from taking into account Freud's interpretations, instead providing an account of how Freud interacted with his patients, contrasting with the canonical version. The conclusion he draws is that Freud's cures were largely ineffectual, when they were not downright destructive.
\end{abstract}

Relevant aspects of the background and circumstances of the cases is provided. Many patients were of aristocratic descent, some enormously wealthy, a significant number were Jewish, while Americans were given priority because of the high value of the US dollar. It also provides an insight into the fading world of fin de siècle Vienna and how incestuous was the Jewish circle of Freud, his family and patients. 
The author shows that the cures written up by Freud were far less than that and there were a number of casualties. Part of the problem was the sheer novelty of early psychoanalysis where rules and boundaries were not established. There was a dichotomy between the cases that the world learned of from Freud's writing and what actually happened.

Does it matter that Freud gave such misleading accounts of these treatments? Borch-Jacobsen has no doubt. Psychoanalysis must be criticised because it refuses to recognise that it creates the reality it purports to describe and attempts to cover up the artifice.

On that basis, one could argue that there was a doppelgänger Freud.

Words: 2916

Text only: 2526 
While Sigmund Freud described very few cases for someone who was in practice for so long, they achieved lasting fame under the names he gave them: Emmy von N.', 'Caecilie N', 'Elisabeth von R.', 'Dora', 'Little Hans', the 'Rat Man', the 'Wolf Man' and the 'Young Homosexual Woman'- in reality, Fanny Moser, Anna von Lieben, Ilona Weiss, Ida Bauer, Herbert Graf, Ernst Lanzer, Sergius Pankejeff and Margarethe Csonka, names that have passed into psychological and literary history.

Of the cases Freud wrote up, we are largely dependent on the information he provided; how accurate this was remains an open question. ${ }^{1}$ While other patients of Freud were not written up in his case studies, information about them has seeped out over the years. ${ }^{2}$

As historians discovered, the Freud Estate, starting with Anna Freud and Ernest Jones and followed by Kurt Eissler, put iron shackles on the archives, citing patient confidentiality as the reason but more likely, as others have noted, to prevent embarrassing details of their treatment from emerging. Most of the records are kept at the US Library of Congress and some embargos have been lifted over time. But it is still a meagre number.

Mikkel Borch-Jacobsen, a leading historian of psychoanalysis, has done a masterly job of excavating details of thirty-eight patients. Those whom Freud saw only for training purposes are omitted (with overlap in a few cases). There are often just snippets of some cases, some described in greater detail and adverse outcomes, such as suicide or drug addiction, which were not known before, are revealed. 
Looking at the cases listed, what becomes apparent is how many patients were of aristocratic descent, some were enormously wealthy, a significant number were Jewish, while Americans were given priority because of the high value of the US dollar at a time of intense financial strain following World War 1 . This was not as much due to the seriousness of their problems (although in some cases, very severe) but Freud's requirement for the high fees.

One of the most enjoyable aspects of the book, although not necessarily intended by the author, is viewing the lives of selected denizens of fin-desiècle Habsburg Empire - the epicentre of Mitteleuropa before the Anschluss - a reminder of the richness of that lost world, if not the many talents that flourished in Vienna at the time.

It was also very incestuous. Many patients were in the Vienna Jewish circle, connected by family or friendship ties. Siegmund Pappenheim, father of Bertha (Anna 0) was the guardian of Martha Breuer (who became Freud's wife) and a friend of Bertha. ${ }^{2}$ Freud, in his letters, freely discussed the progress of her treatment. Gossip was common in these circles and Freud was far from discreet.

Historiography has not been kind to Freud. Psychoanalysis was controversial from the start, the most vehement opposition coming from German psychiatrists. Freud however was seen in an exalted light, largely due to the hagiography written by Ernest Jones in the fifties. ${ }^{3}$ Since then, however, revisionist historians have not as much chipped but smashed 
away large parts of the myth of the founder, leading to an ongoing and vehement public feud between the true believers and the 'Freud bashers', as they are designated. ${ }^{4}$ The Freud estate must be blamed for this. Going to great lengths to hide archival information, they only encouraged the revisionists to persist in their efforts on the basis that so much evasiveness must mean that there is something to hide.

Unfortunately, all too often this turns out to be the case. Anna 0 (Bertha Pappenheim), jointly written with Breuer, was described by Peter Gay as 'the founding case of psychoanalysis'. ${ }^{5}$ The writing on the case that followed listed Breuer's treatment as a cure, as well as later diminishing his role with an account of a pseudo-pregnancy. This was not just a blurring over the facts, but a complete untruth that Freud successively added to in later years.

The detective work of Henri Ellenberger and Albert Hirschmüller completely overturned the canonical version. ${ }^{6}$ Publishing his findings in 1972,7 Ellenberger summed up the case with the arch comment that the famed prototype of a cathartic cure had been neither cathartic nor a cure. 8 Breuer's 'chimney-sweeping' had decisively failed, Pappenheim spent several years in psychiatric institutions, becoming addicted to chloral and morphine; it took seven years before she could resume a normal life.

Hirschmüller, Breuer's biographer, later discovered additional documents. $^{9}$ One of her doctors at Bellevue Sanatorium noted her 'disparaging judgements against the ineffectiveness of science in 
regard to her sufferings'. ${ }^{9}$ The patient herself (perhaps victim is a better term) was less than impressed by her inadvertent role as the index case of psychoanalysis. She was later to say, 'As long as I live, psychoanalysis will never penetrate my establishments', not a ringing endorsement by any means. ${ }^{10}$

From this followed, in Harold Merskey's words, a minor cataract of writing about the case, none of which supported the original view and provided intriguing but untestable explanation for Pappenheim's condition. ${ }^{11}$ The new revelations led to a series of intriguing (if not unprovable) explanations for her condition, each generation it seems coming up with something new. ${ }^{12}$

The series commences with Bertha Pappenheim and concludes with the wealthy American Carl Liebmann. There is no shortage of surprises. Borch-Jacobsen reveals that the 'heroine' of the first case Freud wrote up was ... his wife Martha, whom he hypnotised after several pregnancies when she had difficulty breastfeeding the children. While at pains to hide her identity in his report, the events described are consistent with Martha Freud's pregnancies. Her husband stresses that she was not neurotic, an assessment that everyone who knew Martha would have agreed with. To what Freud described as a 'remarkable achievement', Borch-Jacobsen responds with the comment that never again would Freud be able to report on such an unambiguous therapeutic success. 
This treatment was a prelude to something that Freud would frequently engage in, the violation of analytic boundaries that he was to set up, in the spirit of what Paul Roazen called "the Rabbi May". ${ }^{13}$ Freud's analysis of his daughter Anna is well known and has been extensively discussed. There would few who disagree that this complicated situation had serious consequences for the analysand and took the privileges of "the Rabbi" beyond acceptable limits.

Adele Jeiteles, the mother of Arthur Koestler, was another member of the cultural elite with whom Freud intersected. According to Koestler, his mother saw Freud two or three times. After several visits, she took an immediate dislike to him but later became an enthusiast. What effect this had on her son is debateable, but he spent the rest of his life coming to terms with their relationship.

Ilona Weiss ('Elizabeth von R') was written up as successful treatment of her hysteria. Freud, attributing the condition to her unrequited love for her brother in law, declared her cured and ended the treatment. She remained symptomatic but had a happy marriage to another man. Years later she was to say that Freud 'just a young, bearded nerve specialist they sent me to. He wanted to persuade me that I was in love with my brother-in-law, but that wasn't really so.'

There were casualties. Pauline Silberstein, the unhappy wife of his childhood friend Eduard Silberstein, threw herself from the fourth floor of his building. ${ }^{14}$ The story of Emma Eckstein's treatment is probably the worst case of treatment failure in the account. From a prominent 
Viennese Jewish family, Freud treated her for what seems to have been symptoms of dysmenorrhoea. Enter his whacky friend Wilhelm Fliess, the Berlin ENT surgeon obsessed with the 'nasal reflex neurosis'. Freud arranged for him to perform a nasal operation on Eckstein which was a surgical disaster from which she nearly bled to death and was left with a permanent deformity. ${ }^{15}$ This "bizarre act of medical malpractice"16 showed Freud as his most dogmatic and implacable, insisting on attributing her dysmenorrhoea to hysterical menorrhagia. Surprisingly Eckstein, facial disfigurement and ongoing problems notwithstanding, did not bare any resentment and became an analyst herself.

Katharina, the Alpine shelter owner's niece written up in Studies in Hysteria, had an impromptu consultation with the holidaying Freud. ${ }^{17}$ Freud described her as a case of 'virginal anxiety' arising from an attempted abuse by her uncle, which brought back repressed memories of finding him in bed with her cousin. When he explained the link, she was relieved of symptoms.

We know much more about this case from the detective work of Peter Swales, who discovered that she was Aurelia Kronich and Freud had taken considerable liberties with the chronology of events. ${ }^{18}$ She was 18 , not 13 , at the time, had plenty of reasons to be anxious but there had been no attempted abuse by her uncle. Elizabeth Thornton was later to attribute her symptoms to temporal lobe epilepsy. ${ }^{19}$ 
The 'Rat Man' (Sergius Pankejeff), having passed through the hands of numerous analysts after Freud, has also received much attention, becoming what can only be regarded as a professional analysand. At the end of it all, he was distinctly underwhelmed, saying that he did not recognise himself in Freud's account or in Muriel Gardiner's book; rather "Instead of doing me some good, psychoanalysts did me harm ... That was the theory, that Freud had cured me 100 percent ... To show the world how Freud had cured a seriously ill person ... It's all false."

The case records reveal therapist behaviours which would be quite unacceptable now, notably having affairs with patients. The absence of what today would be considered appropriate boundaries (despite Freud recommending avoidance of intercourse during analysis) was rampant and not just in the Vienna circle. To mention just two, Carl Jung and Oskar Pfister made a regular practice of having affairs with their patients. ${ }^{20}$

This was a feature of both the sheer novelty of psychoanalysis and the establishment of a professional identity. Freud was keen on non-medical analysts (such as his daughter Anna), but it was never clarified whether they were subjected to the same rules as doctors. This can be forgiven as something that was formalised as analytic practice developed, but is less tolerable when the damage is known.

It is difficult to think of a literary account that would match the 
ménage à quatre_involving Gizella Altschul Pálos, her daughter Elma Pálos, Sandor Ferenczi and Freud. Gizella was Ferenczi's longtime patient and mistress, there was a brief affair with Gizella's sister Sarolta, but he became infatuated with her daughter Emma. The latter two went like shuttlecocks between the couches in Budapest and Vienna but Ferenczi eventually married Gizella while Emma went on to another unhappy relationship. The turmoil for the participants was huge and it is difficult to see how Freud could justify (in Analysis Terminable and Interminable) that Ferenczi's analysis had 'a completely successful result. He married the woman he loved.' This was not merely rationalising the situation, it was mendacious.

Horace Frink was another example. Freud's interference in Frink's relationships was quite inexcusable by the standards of the time, as well as the present. His advice to Frink to marry the wealthy former patient Angelika Bijur - or become homosexual - ruined six lives and may have been done to provide funds for his movement in the US. ${ }^{21}$ Later, asked by his daughter what message he would convey to Freud, Frink said 'Tell him he was a great man, even if he did invent psychoanalysis.'22

Judgements on these mishaps should take into account the sheer novelty of psychoanalysis and how long it took to understand that the analyst themselves needed to have stable lives and personalities (counter-transference notwithstanding) and that severe psychiatric problems in analysands were not to be dealt with in terms of unresolved oedipal complexes or repressed homosexuality. 
Freud could not accept that his messianic status could have devastating effects on his supporters and patients when he withdrew his support. Horace Frink never recovered from the perceived rejection when Freud ended his analysis and Viktor Tausk committed suicide as a result.

Loe Kann, Ernest Jones' mistress, having been his analysand before going on to first Freud and then Ferenczi who had previously analysed Jones (more shuttling between Vienna and Budapest). A morphine addict who complained of anorgasmia, she failed to improve, but married another Jones (this time Davey).

Borch-Jacobsen is to be congratulated on his tenacious pursuit of every tiny lead in an attempt to flesh out the cases. In doing so we learn much about Freud's practice, finding far more shades of grey than were known or expected. The author is at pains to state that he has refrained as far as possible from taking into account Freud's interpretations and those who seek a confirmation of Freud's stories will be disappointed. What instead is provided is an account of the Freud of his patients, which will be difficult to reconcile with the canonical version. The main conclusion he draws from these cases (with a few ambiguous exceptions, such as Ernst Lanzer, Bruno Walter and Albert Hirst) is that Freud's cures were largely ineffectual, when they were not downright destructive. 
While Borch-Jacobsen remains carefully objective in describing the cases, his views on Freud's veracity are expressed elsewhere:

"In the domain of psychotherapy, a co-construction of reality is inevitable and normal. There, one never finds facts, only artefacts. If psychoanalysis must be criticised, it is not because it fabricates the evidence it adduces, nor because it creates the reality it purports to describe. It is because it refuses to recognise this and attempts to cover up the artifice." 23

It could not be better put. 
${ }^{1}$ Borch-Jacobsen M. How a Fabrication Differs from a Lie. LRB, Vol. 22 No. 8 • 13 April 2000.

${ }^{2}$ Swales P. Freud, his teacher and the birth of psychoanalysis. In: Stepansky PE, ed. Freud, Appraisals and Reappraisals, Vol. 1. New York: The Analytic Press, 1986.

3 Jones, Ernest. The Life and Work of Sigmund Freud. 3 vols. New York: Basic Books, 1953-1957

${ }^{4}$ For a good review, see: Frederick Crews (1995). The Memory Wars: Freud's Legacy in Dispute. New York: The New York Review of Books.

${ }^{5}$ Peter Gay. Freud: A Life for Our Time. New York: AnchorBooks,1989.

${ }^{6}$ Kaplan R. O Anna: being Bertha Pappenheim--historiography and biography. Australas Psychiatry. 2004 Mar;12(1):62-8.

${ }^{7}$ Ellenberger HF. The story of 'Anna O.': a critical review with new data. History of Behavioural Sciences 1972; 8: 267-295.

${ }^{8}$ Ellenberger HF. The story of 'Anna 0.': a critical review with new data. Ibid.

${ }^{9}$ Hirschmüller A.The Life and Work of Joseph Breuer: Physiology and

Psychoanalysis. New York: New York University Press, 1989.

10 Guttmann GM.The Enigma of Anna O. A Biography of Bertha Pappenheim.

Berkeley, CA: Publishers Group West, 2001.

11 Merskey H. Anna O. had a severe depressive illness. British Journal of

Psychiatry 1992; 161: 185-194. Like the Jack the Ripper case, each generation adds it own interpretation of the case.

12 Kaplan R. 0 Anna: being Bertha Pappenheim--historiography and biography. Ibid.

13 Paul Roazen. Freud And His Followers. Penguin Books, 1975, page 437.

${ }^{14}$ At the time Freud worked at 8 Maria Theresienstrasse, moving to 19 Bergasse after the incident.

${ }^{15}$ Fliess left a half metre of gauze in the operation site which rapidly became infected.

16 Launer J. The case of Emma Eckstein. Postgrad Med J. 2016 Jan;92(1083):5960.

17 Sigmund Freud, Joseph Breuer: Studies in Hysteria. Penguin Books, London 2004.

18 Swales, Peter J., 'Freud, Katharina, and the First "Wild Analysis"', in Freud: Appraisals and Reappraisals: Contributions to Freud Studies, ed. Paul Stepansky (Hillsdale, NJ, 1988), vol. III, pp. 80-163.

19 Elizabeth Thornton. The Freudian Fallacy. Paladin Books, 1983.

${ }^{20}$ Perhaps most famously with Sabina Spielrein in Jung's case - as depicted in the movie A Dangerous Method.

21 The Master's mad move.

https://www.theguardian.com/books/1999/jan/30/sigmundfreud. Accessed 11 January 2022.

${ }^{22}$ Frink, who appears to have been manic depressive, later committed suicide. 
${ }^{23}$ Mikkel. How a Fabrication Differs from a Lie. LRB. vol. 22 No. 8, 13 April 2000. 